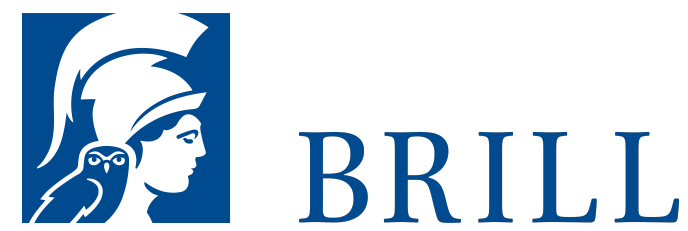

\title{
Christliches Naturrecht in der pluralistischen Moderne
}

Jacques Maritains Kritik der Allgemeinen Erklärung der Menschenrechte

Author: Phillipp Saure

Das Verhältnis von Menschenrechten und Religion bildet ein hochaktuelles Feld der politischen Philosophie. Vor diesem Hintergrund untersucht das vorliegende Buch die Sicht des katholischen Denkers Jacques Maritain (1882-1973) auf die Allgemeine Erklärung der Menschenrechte.

Die Erklärung von 1948 verdankt ihren Erfolg mutmaßlich nicht zuletzt einer weitgehenden weltanschaulichen Neutralität.

Mari-

tain vertrat während der Genese des Dokuments eine explizit christliche Menschenrechtstheorie. Paradoxerweise gilt er aber als eine Art intellektueller Gewährsmann der Erklärung. Das Buch zeigt, wie Maritain einerseits tatsächlich eine gewisse weltanschauliche Neutralität der Erklärung rechtfertigte, diese aber zugleich in einem religiös geprägten Menschenrechtskanon aufheben wollte. Maritains Theorie ähnelt damit auch und hebt sich zugleich ab von der Konzeption des überlappenden Konsenses des US-Philosophen John Rawls.

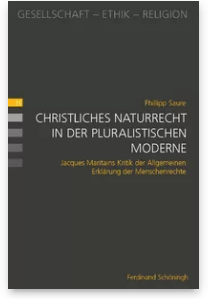

Pages: 327

Seiten

Language:

German

Subjects:

General,

Theology and

World

Christianity

Publisher: Brill |

Schöningh

Series:

Gesellschaft -

Ethik - Religion,

Volume: 11

E-Book (PDF)

Released online: O2 Sep 2019

ISBN: 978-3-

657-78765-4

List price

Paperback

Publication date: 11 Aug 2017

ISBN: 978-35o6-78765-1

List price 
Phillipp Saure studierte Philosophie an der Ruhr-Universität Bochum und der École Pratique des Hautes Études in Paris. Seit 2008 arbeitet er als EU-Korrespondent in Brüssel. 2016 Promotion im Fach Politische Wissenschaft an der FriedrichAlexander-Universität Erlangen-Nürnberg.

For more information see brill.com

\author{
Order information: Order online at brill.com \\ +44330 3330049 | customerservices@brill.com \\ Submission information: brill.com/authors
}

Titles published by Brill | Fink, Brill | mentis or Brill | Schöningh: +49(o)71 5413279216 | brill@brocom.de 